\title{
Towards antagonistic cosmopolitanism. A theoretical attempt to work though the controversy about the shape of global democracy
}

Keywords: agonism, the political, cosmopolitanism, global democracy, cosmopolitan democracy

\begin{abstract}
The article presents the analysis of the relation between two concepts, namely cosmopolitan democracy and agonistic multipolar order, whose author is Chantal Mouffe, in the context of the dispute about the preferred shape of global democracy. Both approaches are presented in the literature as opposing. The main thesis of the present article is the possibility of connecting them, but according to dialectical principles. The point is not about a smooth consensus but about the fact that the contradictions between those views can be treated as a condition of their interweaving. To this aim, I use two theoretical concepts: of antagonistic cosmopolitanism by Tamara Caraus and of antagonistic global constitutionalism by Christof Royer. On this basis I claim that Mouffe's rejection of cosmopolitanism is not thoroughly coherent with her own assumptions. I acknowledge her argumentation that cosmopolitan democracy might lead to pluralism without antagonism but at the same time I suggest that Mouffe's postulate of the multipolar order can lead to pluralist antagonism without agonism. It is only the establishment of cosmopolitan institutions and rules that will allow for really agonistic and radically pluralized global politics, thanks to which it will be possible to solve the contemporary world problems effectively. For these reasons agonistic cosmopolitanism can be regarded as the most optimal variant of global democracy.
\end{abstract}

* ORCID ID: https://orcid.org/0000-0001-9655-5075; habilitated doctor in the discipline of political science; the Institute of Political Sciences and Administration of the University of Opole; E-mail: kminkner@uni.opole.pl 
The dynamics of globalization processes caused a necessity to develop normative and functional solutions in the field of the world politics. Those scientists who spoke for the democratic cosmopolitan politics proved to be the most active in this field. The prominent representatives of this approach such as Daniel Held and Daniele Archibugi ${ }^{1}$ as well as Ulrich Beck ${ }^{2}$ assume that if we have to do with serious social and economic challenges on the scale of the whole world (climate warming, social inequalities, migrations, human rights) which cannot be coped with by national states, then global structures of demoliberal political control should be established. On the other hand, other theoretical views pointing to the weaknesses of the cosmopolitan project appeared on the wave of criticism toward the cosmopolitan approach blamed for Utopianism. One of the more interesting ones in this sphere is the concept of an agonistic vision of the political order developed by Chantal Mouffe. In her opinion, cosmopolitan democracy would be another incorporation of the global hegemony of liberalism and this is the reason why she spoke for the perspective of a multiplicity of decision-making centers and ideological perspectives on the global scale ${ }^{3}$.

In the present reflections, I intend to juxtapose the cosmopolitan with agonistic concepts in a broader context of the controversy concerning democracy in the times of global capitalism. I would like to reflect on whether the cosmopolitan concept might enrich the agonist approach, but also the other way round, whether the postulates of advocates of global democracy can be reconciled with the propositions of agonists. Such a look at the problem is cognitively interesting since both these concepts are treated in scientific debate as contradictory. Nevertheless, I would like to analyze the thesis that they can be theoretically linked. And I do not mean a smooth compromise according to the rule of averaging one and the other views. I believe that we should look at both approaches in a dialectical mode. This means that the contradiction between them is a condition of common co-occurrence which has both practical and normative importance. What is significant here is the possibility of developing such a project which will be at the same time realistic and based on axiologically acceptable basis. In addition, it should guarantee solving global social problems in an effective manner.

1 D. Archibugi, D. Held, Cosmopolitan democracy: an agenda for a new world order, Cambridge 1995.

2 U. Beck, Władza i przeciwwładza w epoce globalnej. Nowa ekonomia polityki światowej, Warszawa 2005.

3 Ch. Mouffe, Polityczność: przewodnik krytyki politycznej, Warszawa 2008, pp. 133-136. 
I place my considerations within a broadly understood critical perspective. In reference to globalization it means a completely different standpoint from that preferred by such optimists as Thomas Friedman. They think that above all globalization enabled progress, broadened freedom and reduced inequalities ${ }^{4}$. In his opinion, thanks to global technologies the world has become flatter since it gives different entities the possibility of the world economic activity based on equal rights, which contributes to the prosperity of the whole society. Friedman did not try to hide, either, that his approach to globalization favoured American values which should triumph all over the world ${ }^{5}$. I think that this type of vision is not only short-sighted, or even ignorant, but also conceptually too reductionist. It overlooks social inequalities and exclusion, hybridity of global culture and deficits of democracy. Like David Hicks, I think that we should look at globalization through the light of engaged global education, thus considering the contradictions: equality/inequality; justice/injustice; conflict/peace; environmental devastation and protection; alienation/participation ${ }^{6}$. As emphasized by Jie-Hyun Lim, critical studies on globalization require focusing on bottom-up globalization, which means rooting global processes in social practices. It is also of key importance to reject the assumption that differences and variability of human differences and variability of human experiences can be erased in the name of artificial universality ${ }^{7}$. The importance of bottom-up globalization is also emphasized by Boaventura de Sousa Santos and Mouffe, who refers to him. The key point of reference for them are the articulations of counter-hegemonic excluded and minority groups, especially those embedded in the cultural contexts of the South. In their opinion, thanks to such an approach discourses of democracy and human rights can be denaturalized and their alleged universalism can be undermined ${ }^{8}$. Interestingly, despite a number of theoretical differences, similar clues can also be found in some advocates of cosmopolitan politics. For example, Beck emphasizes that cosmopolitization does not mean universalism but rather a lot of competing lifestyles and different varieties of rationality

4 T. Friedman, Lexus i drzewo oliwne: zrozumieć globalizacje, Poznań 2001.

5 T. Friedman, Świat jest płaski: krótka historia XXI wieku, Poznań 2009.

6 D. Hicks, Thirty Years of Global Education: A reminder of key principles and precedents, «Educational Review» 2003, vol. 55, No. 3, p. 271.

7 J.-H. Lim, What is Critical in Critical Global Studies?, «Global Studies in East Asia» 2017, vol. 10, No. 16, https://www.21global.ucsb.edu/global-e/march-2017/what-critical-criticalglobal-studies (12.01.2021).

8 Ch. Mouffe, Which World Order: Cosmopolitan or Multipolar?, «Ethical Perspectives» 2008, vol. 15 , No. 4, pp. 459-460. 
which we experience every day because of globalization absorbed from within. That is why cosmopolitanism cannot mean homogenization but rather "internalization of the Other" 9

The present article favours the agonistic approach; nevertheless, I also treat it polemically, especially as far as Mouffe's variant is concerned. Viewing it in a dialectical way - I believe that supplementing Mouffe's agonistic standpoint with the elements of the cosmopolitan approach will only make it possible to make her assumptions coherent and develop them in a consistent manner. I will attempt to prove that it will be the most creative and at the same time functional analysis of controversies about democracy in the times of global capitalism.

\section{Premises of global democracy}

The concept of global democracy is closely linked to globalization itself, and especially with global challenges following from the former. The primary factors in these changes certainly include the developmental dynamics of global turbo-capitalism as contemporary capitalism was called by Edward Luttwak. It is the world free market economy, deprived of any control, whose only measure is profit which is identified with social happiness and all human needs. E. Luttwak thinks that political power shifted from the political to the economic, which ultimately subordinated the states and societies to economic goals. The main problem is that this system, which cares exclusively about economic effectiveness, generates a lot of social problems such as poverty, unemployment, collapse of social structures, emotional loneliness of an individual and the weak political power cannot cope with them. The reason for all of this is that the earned profit is distributed in a very unequal manner ${ }^{10}$.

Among the consequences of globalization important from the point of view of the debate on global democracy, dangers for the contemporary state are particularly significant. As claimed by Paul Kennedy, they come from two sides, namely the regional and supranational ones. As a consequence, the state that we know at present can be too big for some problems and two small for others, which might generate new interior and regional conflicts ${ }^{11}$. Zygmunt Bauman adds that global processes under-

9 U. Beck, The Cosmopolitan Society and Its Enemies, «Theory, Culture and Society» 2002, vol. 19, No. 1/2, p. 18.

10 E. Luttwak, Turbokapitalizm: zwycięzcy i przegrani światowej gospodarki, Wrocław 2000.

11 P. Kennedy, U progu XXI wieku: (przymiarka do przysztości), Londyn 1994, pp. 142-156. 
mined the sovereignty of the state and led to its disinheritance while no new global order has emerged. And - in his opinion - this is what globalization is - a reflection of the new disorder of the world. "Weak fake states easily give in to be reduced to the function of police districts securing a little bit of order necessary to run business [...]"12. On the other hand, lately we have observed nationalistic and state-oriented ressentiments which are inspired by various populist movements. It cannot be denied, either, that certain democratic and authoritarian countries are really strong all the time (e.g. the USA, China). For this reason the statement might be more justified that the role of the state has not become weaker but it has changed on many levels in relation to the authorities and governance. This is indicated by international reports which emphasize that an increase in the importance of non-state entities in the processes of global decision-making with which the states will have to build platforms of cooperation ${ }^{13}$. Nevertheless, Z. Bauman is right in saying that this type of processes will generate disorder unless they get regulated.

In this way the problem of global democracy appears. For many researchers the establishment of a global democratic system is to be an instrument of greater socialization of globalization and political control by the world capitalism which weakened the state and changed democracy and politics into a zombie, as emphatically called by to U. Beck ${ }^{14}$. The situation is, however, complicated by the fact that global capitalism also undermined the processes of democratization. As follows from a report of Freedom House, the number of democratic countries decreased in the years 2006-2018 and the parameters of democracy in West European countries or the USA fell ${ }^{15}$.

Fluctuations in democratization processes are also reflected on the international level. Researchers of politics have for a long time observed the problem of the weakness of democratic governance on a global scale calling it with the name of a democratic deficit. Kate Macdonald claims that the problem is the tension between the territorially anchored systems of democratic power within the state and the transnational systems of governance on the world scale ${ }^{16}$. This deficit concerns both particular

12 Z. Bauman, Globalizacja: i co z tego dla ludzi wynika, Warszawa 2006, p. 82.

13 See, e.g.: Future State 2030: The global megatrends shaping governments, The Mowat Centre at the School of Public Policy and Governance, University of Toronto 2014.

14 U. Beck, The Cosmopolitan Society..., p. 41.

15 Freedom in the World 2019: Democracy in Retreat, Freedom House 2019, p. 7.

16 K. Macdonald, Global democracy for a partially joined-up world toward a multi-level system of public power and democratic governance?, [in:] D. Archibugi, M. Koenig-Archibugi, R. Marchetti (eds.), Global democracy normative and empirical perspectives, Cambridge 2012, p. 186. 
countries, international organizations and the whole global international system within which effective governance only partly coincides with democratic procedures. The point of the concept of deficit are not retreats from democracy but different global processes which wash away state democracy and give the real political importance to the entities which are not fully subjected to a democratic political control and whose source of influence is not the electoral mandate. Researchers point not only to global international corporations with no national loyalty and only with economic interests but also to such organizations as UNO. It follows from the comparison by Citizens for Global Solutions that 10 most populated countries of the world, which constitute nearly $60 \%$ of the global population and generate almost 48\% of the world GDP, have only 5.2\% votes in the General Assembly of UNO17. A well-known researcher and spokesman for global democracy, D. Archibugi indicates, however, that if we adopted the principle of population majority, then this majority could be built basing on six states, which would not be democratic either. Still less obvious as far as the deficit of democratic governance is concerned are examples of non-governmental international organizations which frequently have noble purposes connected with peace and human rights. Researchers put questions about their real interests, legitimization and criteria of involvement in the structures of global decision-making. It is emphasized that not infrequently are these organizations of considerable influence and, at the same time, quite small with the management which is not always clearly appointed ${ }^{18}$.

Gráinne de Búrca, on the other hand, draws attention to the problems of compensating for democratic governance on a global scale. In her opinion, it leads to the deepening of the deficit of global democratic governance. Advocates of compensation practices assume that democracy cannot be transferred from the national to the international arena and this is the reason why some kind of substitute mechanisms in relation to democratic governance need to be found, at the same time keeping particular procedures of democratic power. G. de Búrca enumerates such solutions in this respect as involving decision-makers who possess expertise or the status of social representativeness, while others place emphasis on the transparency of the decision-making process and the establishment of the rules of open deliberation with the participation of

17 Source: https://globalsolutions.org/federation/global-democracy-and-governance/ (03.01.2021).

18 W. Anioł, Deficyt demokratyczny w systemie globalnym, «Studia Europejskie» 2002, No. 4, p. 20. 
actors oriented at a rational exchange of arguments ${ }^{19}$. Advocates of such solutions usually claim that solving global problems in an effective way is more important than democracy.

Different variants of global democracy were supposed to be the answer to different signs of a deficit of global democracy.

\section{Around the concept of cosmopolitan democracy}

The concept of global democracy is much more complex that it is commonly believed. Three different models usually occur in the literature. The first one is called confederate, intergovernmental but there are also such descriptive names as "an honest, voluntary association of democratic countries" 20 . John Ruggie defines the intergovernmental model as an institutional form within which the relations between three or more states are coordinated on the basis of generalized rules of proceedings ${ }^{21}$. Advocates of this variant claim that the world politics is democratic to the degree in which each sovereign state is internally democratic. This view does not provide for a direct access of citizens to the confederate institution and thus they are democratically represented outside the country only by the national government.

A few objections can be raised towards the confederate model. Firstly, as shown by reports of such organizations as Freedom House, in 2018 only $44 \%$ of countries could be called free. These data are distributed even less optimistically considering the social aspect. In 2018 only 39\% of the world population lived in free and democratic countries ${ }^{22}$. Secondly, national states do not have full control over international institutions. This means that non-state entities are able to reserve their own space for activity on the international scale. Thirdly, transnational networks and private forms of management spread outside the state and they have influence on the citizens while national states do not usually have a voice in those structures.

19 G. De Búrca, Developing Democracy Beyond the State, «Columbia Journal of Transnational Law» 2008, vol. 46, No. 2, pp. 101-158.

20 D. Archibugi, M. Koenig-Archibugi, R. Marchetti (eds.), Global democracy normative and empirical perspectives..., p. 7.

21 J. Ruggie (ed.), Multilateralism Matters: The Theory and Praxis of an Institutional, New York 1993, p. 10.

22 Freedom in the World 2019..., p. 8. 
The second variant of global democracy emerges from the limitations of the intergovernmental model and it can be called democratic governance ${ }^{23}$ or "global democracy of stakeholders" as it is emphatically called by Terry Macdonald. He means different aspects of broadly understood public power with the participation not only of states but also communities of interests and entities whose representations do not come from elections, for example international organizations, transnational corporations and representations of social groups and civic environments ${ }^{24}$. As emphasized by G. de Búrca, this approach assumes that if the sociopolitical forces cross state borders, the state cannot be the only point of reference, which is what supporters of the confederate perspective want. Advocates of global governance claim that democracy concerns the state and now there is no possibility to shift it onto the supranational level. This, however, does not mean that social processes cannot be effectively and democratically governed. For the supporters of this form, for example G. de Búrca, the essence of programs introducing this type of formula are reforms of different international organizations (e.g. International Monetary Fund within the Poverty Reduction Strategy) ${ }^{25}$.

Nevertheless, some researchers want to go even further in the direction of breaking with the state and they desire closer unification on the world scale than it follows from the model of governance. In this way the third model emerges, namely global democracy in the form of an integrated global political community. Here, it is assumed that the institutions of democratic power are installed on the model of the state and they have the decision-making competences in the sphere of solving problems of the worldwide character. This level is supposed to complete two lower levels of political power: local and state ones. The first model emphasized the importance of states, the second the importance of different social and economic stakeholders while in the third model the most important are the citizens of the world themselves without the mediation of organizations, states in particular. Federalist integration is considered here the main institutional rule and the main institutions are to be the bodies of the global executive (world government), the legislative (world parliament) and the judiciary powers. It is also assumed that

23 R. Marchetti, Global Democracy: For and Against. Ethical Theory. Institutional Design, and Social Struggles, London-New York 2008, pp. 139-142.

24 T. Macdonald, Global Stakeholder Democracy: Power and Representation. Beyond Liberal States, Oxford 2008.

25 G. De Búrca, Developing Democracy Beyond the State..., pp. 129 ff. 
political decisions made by the world government would be applicable directly towards the citizens, and not the states.

Independently of the three aforementioned pure variants of global democracy, particular authors tried to develop more specific concepts which in various proportions connected the features of particular variants. The variant of global democracy functioning under the name of cosmopolitan democracy, popular now, can be perceived in such a perspective. This is a project aimed at the development of democracy within the nations, between the states and on the global level. The main premise in its construction is the assumption that democracy is not a closed set of procedures but a process which never ends. If the world gets globalized, then democratization processes should follow this path ${ }^{26}$. The common elements of this variant and the federation approach is the assumption on the necessity of transferring democratic institutions onto the world level. The point first of all refers to installing institutions of civic representation integrating the activities of different social and economic stakeholders ${ }^{27}$. As emphasized by D. Archibugi, there are problems which are really global and concern all people; on the other hand, there are those which concern limited communities (e.g. religious communities, international corporations) but from many countries. Political cosmopolitans claim that this challenge can be most effectively coped with by global democratic institutions which should have the competences to manage the matters of global reach (e.g. climatic issues) as well as to interfere into particular states every time serious violations of human rights occurs. Advocates of cosmopolitan democracy emphasize, however, that their concept does not assume full modeling of state structures on the global level. They do not mean replacing the state but rather strengthening power in the world where the state became weak because of globalization processes. As emphasized by Held, cosmopolitan democracy does not require weakened state power but it is rather about complementing it on the local and global levels. The rules of inclusiveness and subsidiarity should be applied in this respect, which means that decisions should be taken close to the citizens and considering their voices and opinions. It is

26 D. Archibugi, Cosmopolitan Democracy and its Critics: A Review, «European Journal of International Relations» 2004, vol. 10, No. 3, pp. 437-473.

27 See more in: D. Held, Democracy and the global order: from the modern state to cosmopolitan governance, Stanford 1995. 
individuals, assumed to be equal to each other regardless of the culture circle, who are the most important in this model 28 .

Researchers dealing with cosmopolitan democracy present it as a possible though multi-stage plan which can comprise confederate activities, international governance as well as certain federation solutions. For Held, of equal importance are democratic networks of civic forums, increased transparency of non-governmental organizations as well as the establishment of police and military forces which would guard the new cosmopolitan order ${ }^{29}$. The suggested cosmopolitan initiatives also include the necessity of a democratic reform of the existing international organizations. For example, ideas are put forward referring to UNO and saying that delegates to the General Assembly should also be elected by the opposition, and in case of the Security Council it is postulated that civic consultancy organizations be considered ${ }^{30}$. Advocates of cosmopolitan democracy also present ideas to appoint new institutions that would have to ensure social representation on the global level. One of the first initiatives in this respect was put forward in "Foreign Affairs" by Richard Falk and Andrew Strauss, who came up with an idea to establish the world parliament. According to them, his type of institution is necessary in order to integrate the citizens' activities, which are now entangled in contradictory interests of social organizations and transnational corporations, on the world scale. The authors believe that this type of institution would be a global forum for the exchange of thoughts on the environment or economic justice, and could also constitute a form of civic control over such organizations as WTO. An organ of this kind would not be created by states and its composition would come directly from the citizens. What is important, the parliament would not be some institution of public power out of touch with reality but it could be incorporated into the UNO structure as the second chamber of the General Assembly ${ }^{31}$. Falk and Strauss's idea is also compatible with the proposition by Beck who demanded political entities adjusted to cosmopolitan politics and he came up with a proposition of establishing cosmopolitan parties, which means those which represent transnational interests in a transnational

28 D. Held, Cosmopolitanism: globalisation tamed?, «Review of International Studies» 2003, vol. 29, No. 4, pp. 465-480.

29 Ibidem, p. 478.

30 D. Archibugi, Principles of cosmopolitan democracy, [in:] D. Archibugi, D. Held, M. Köhler (eds.), Re-imagining political community: studies in cosmopolitan democracy, Stanford 1998, p. 221.

31 R. Falk, A. Strauss, Toward global parliament, «Foreign Affairs» 2001, vol. 80, No. 1, pp. 212-220. 
way $^{32}$. It also deserved to be added that the idea of a global parliament was also taken up by various non-governmental organizations (e.g. Democracy Without Borders) which have conducted a civic campaign in this direction since $2007^{33}$.

A number of critical arguments have been formulated in relation to the project. Some were afraid of a technocractic global power with a wide range of competences which - instead of extending the citizens' influence - could restrict it even more. Objections also appeared that cosmopolitans did not consider the conflicting interests, which idea was not supported by D. Archibugi, according to whom the opposition of critics of cosmopolitan democracy resulted just from their endangered interests ${ }^{34}$. Some, including Chantal Mouffe, also raised axiological objections according to which the cosmopolitan formula meant imposing the values of the western world on the states and societies from other culture circles ${ }^{35}$.

One of the objections frequently raised by critics toward cosmopolitans was the utopian character of the whole project. I share this opinion but I mean the sense of the concept "utopia" which was assigned to it by Karl Mannheim. He compared the concepts of utopia and ideology as two types of transcendental thinking about political reality. Ideology was considered by him to be those systems which cannot be realized in practice and when they are realized their original assumptions are always departed from. Utopia, on the other hand, was viewed by him in a relativistic manner and meant projects of changes which are impossible to realize exclusively within a given ideological order. Utopia is determined by the dominating ideology while ideology - by those whose aspiration is change. Mannheim himself thought, however, that ideological elements function within utopia, which we see when it is incorporated in life ${ }^{36}$. Looking at the project of global democracy through the lenses of cosmopolitans we can state that cosmopolitan democracy is a transgressive political concept since it crosses the present horizon of probable political events; it does not only exceed the political reality and the conceptual assumptions of the contemporary system but also responds to its weaknesses and challenges. According to Beck, global threats gave rise to

32 U. Beck, The Cosmopolitan Society..., p. 41.

33 M. Brauer, A. Bummel, A United Nations parliamentary assembly a policy review by Democracy Without Borders, Berlin 2020.

34 See more in: D. Archibugi, Cosmopolitan Democracy and its Critics..., pp. 453-464.

35 C. Mouffe, Democracy in a Multipolar World, «Millennium: Journal of International Studies» 2009, vol. 37, No. 3, pp. 549-561.

36 See more in: K. Mannheim, Ideologia i utopia, Lublin 1992, pp. 161-174. 
a global community of risk which is associated with the same fears. Beck wrote that this community is suffering now from a lack of the political entity because the state does not prove itself in this role any more. It is cosmopolitan democracy as a new utopia which is expected to get best adjusted to the actually existing cosmopolitan society which is a product of globalization, including risk globalization ${ }^{37}$.

On the other hand, what is ideological in a cosmopolitan project? I believe that it is largely a post-political project connected with the ideology of liberal democracy, or even political liberalism itself. In this place the agonistic attitude should be introduced which on this level expressed a complex criticism of the political assumptions of cosmopolitans.

\section{Agonistic criticism by Chantal Mouffe toward cosmopolitan democracy}

The majority of researchers representing the agonistic paradigm point to three basic components, namely pluralism, conflict and tragedy ${ }^{38}$. Pluralism, as indicated by Christof Royer, means a multiplicity and differentiation of individuals and groups but according to a different rule in comparison to typical liberalism. Liberalism consider multiplicity to be the fact to be tolerated, whereas agonists raise it to the rank of value to be celebrated because multiplicity cannot be erased. What is more, taking multiplicity into consideration is the foundation for individual and collective identities to get constituted ${ }^{39}$. Referring to conflicts, agonists consider them desirable, inevitable and they ascribe high social value to them. They claim that unity and political harmony are assumed to be impossible. What is more, real democratic struggles permeate the whole society and they are not limited but to the institution of state. As a result, democracy is an eternal process susceptible to disturbance and permanent revival. As indicated by Adrian Little and Moya Lloyd, this is also connected with continuous contestation of the regimes of the binding cultural meanings which are a condition of social intelligibility ${ }^{40}$.

37 U. Beck, Społeczeństwo ryzyka. W drodze do innej nowoczesności, Warszawa 2004, pp. 60-65.

38 M. Wenman, Agonistic Democracy. Constituent Power in the Era of Globalisation, Cambridge University Press 2013, pp. 28-58.

39 C. Royer, Evil as a crime against humanity: confronting mass atrocities in a plural world, Palgrave Macmillan 2021, p. 196.

40 A. Little, M. Lloyd (eds.), The politics of radical democracy, Edinburgh University Press 2009, pp. 1-12. 
In case of the tragic vision of the world, on the other hand, the point is to contradict the liberal narrations on progress which would ultimately ensure that a democratic political community will emerge which will be based on Reason.

In case of Chantal Mouffe's agonistic vision of politics, tragedy has a special, anti-essential character. This means breaking up with the concept of the law of nature, universal values or objective truth. In this view, democracy or human rights, which are by most advocates of political cosmopolitism regarded as natural values, by Mouffe are considered to be particular. According to the author of The Return of the Political, postmodern cognitive assumptions are of key importance from the democratic point of view since they mean a lack of ultimate criteria in solving conflicts in democracy ${ }^{41}$. David Matijasevich thinks that this leads to the so-called paradox of agonistic politics: on the one hand, there is no final certainty concerning the political power and the organization of political community, while on the other, democratic politics is largely connected with working through this lack of certainty. The assumption that a political community does not have any final basis as a consequence leads to the claim that it is always based on subordination, exclusion and conquest. On the other hand, within the agonistic concept each form of power is never sanctified. And therefore, it is always subject to being questioned ${ }^{42}$. For this reason, agonists draw the conclusion that contemporary democracy should be maximally pluralized as only then do we have a guarantee that particular interests are really represented in public space. This type of democracy is called radical democracy by such agonists as Ernesto Laclau and Chantal Mouffe ${ }^{43}$. In her works concerning both democracy in the state and the international system, Mouffe emphasized, on the other hand, that pluralism has to consider the level of the political, that is the fundamental insurmountable social antagonisms ${ }^{44}$. In her opinion, the problem with different theoretical projects of democracy nowadays, including cosmopolitan democracy, is that even if they do notice pluralism, they remove it from the field of the political, which stands at the basis of each politics.

Mouffe refers in a particularly critical way to John Rawls and Jürgen Habermas's deliberative concepts, which are also considered to be the

41 Ch. Mouffe, The return of the political, Verso, London-New York 1993, pp. 9-22.

42 D. Matijasevich, Radical democracy and its limits, Palgrave Macmillan 2019, p. 3.

43 E. Laclau, Ch. Mouffe, Hegemonia i socjalistyczna strategia: przyczynek do projektu radykalnej polityki demokratycznej, Wrocław 2007.

44 Ch. Mouffe, Politycznośc: przewodnik krytyki politycznej..., p. 23. 
views on global democracy ${ }^{45}$. Mouffe thinks that even if deliberationists take conflicts into consideration, ultimately they want to overcome them though a rational, but in fact utopian consensus. As claimed by the Belgian researcher, if we adopt the assumption on the existence of deeper antagonisms in the field of the political, in the sphere of politics they can only be slightly disarmed through various formal and institutional solutions but they are impossible to erase. Hence, the essence of effective democracy is for Mouffe passing from antagonism to agonism, and not to utopian unity. As Carl Schmitt saw it, antagonisms are relations based on the contradiction between an enemy and a friend. They are of existential character since they mean a life-and-death struggle (if only potentially) ${ }^{46}$. Agonism, on the other hand, means transferring antagonism onto the level of politics, the result of which is that an enemy becomes an opponent. We can disagree with them radically but we think that they have the full right to function in the community ${ }^{47}$.

Mouffe's concepts are completed by her theses on hegemony. According to those assumptions, each social objectivity or subjectivity is inherent in the relations of power so it is constituted from the outside as a product of hegemonic forces. Hegemony does not simply mean power created as a result of a conscious process of political expression by competing groups but a result of accidental discursive relations of the power and social objectivities, which are not at all of natural and necessary character. For example, democracy and liberalism are two completely different political dimensions based on equality and freedom, which in the past were treated as opposing. They got tied together in the present and this bond got naturalized, as a consequence of which a new hegemonic order appeared - liberal democracy ${ }^{48}$. According to Mouffe, demoliberal hegemony, both in particular countries and in the international system, negates pluralism and conflict, and thus it strives at creating a community based on illusory consensus. As a result, tensions are suppressed because social interests do not get their real reflection in the public sphere, which leads to their substitutive articulation in radical forms. This is how Mouffe explains the popularity of populisms in the world as

45 J. Kuyper, Global Democracy, [in:] E. N. Zalta (ed.), The Stanford Encyclopedia of Philosophy, Winter 2016, https://plato.stanford.edu/archives/win2016/entries/global-democracy (23.10.2020).

46 C. Schmitt, Pojęcie polityczności [in:] C. Schmitt, Teologia polityczna i inne pisma, Kraków 2000, pp. 191-250.

47 A complex picture of the agonistic concept was presented by Ch. Mouffe in Agonistyka. Polityczne myślenie o świecie, Warszawa 2015.

48 See more in: Ch. Mouffe, Paradoks demokracji, Wrocław 2005. 
well as extreme signs of extremism in the form of Islamic terrorism ${ }^{49}$. On the other hand, Mouffe emphasizes that no hegemony is necessary and that is why it can be questioned through counter-hegemonic practices.

The vision of international order according to Mouffe grows from her criticism of cosmopolitan democracy as an extension of liberal democracy or deliberative democracy in the global sphere ${ }^{50}$. "My main objection toward the cosmopolitan approach is that independently of the way it is formulated it postulates the existence of the world over hegemony and sovereignty, thus negating the dimension of the political. What is more, it is usually based on the universalized Western model thus leaving no place for the multiplicity of the possible solutions. We should bear in mind that imagining the goal of politics - whether on the national or international levels - as the establishment of consensus about one single model eliminates the possibility of validated disagreement, thus creating a space facilitating the appearance of the form of antagonism characterized by violence" 51 . Here Mouffe speaks in a similar spirit as Schmidt, who was one of the first to criticize the concept of an international political community, acknowledging that it would be a new type of hegemony. "Here is the end of the political. Humanity creates unity, a theoretically befriended community. There is no hostility here. There are only partners in controversies. The world politics was replaced by the world police. [...] The police is not, however, apolitical. Here we have the world politics based on pan-interventionism. This is a very intensive form of politics [...], namely the world politics of a domestic war"52. It clearly follows both from what Mouffe and Schmitt said that the cosmopolitan consensus is but a hegemonic façade. For Mouffe, the variant of global democracy is of no importance. She opposes not only cosmopolitan democracy but also the project of global governance - because of post-politicality, which is a technical approach to global challenges. Ideological motifs are also secondary for Mouffe. She realizes that Held's cosmopolitan vision is progressive and the author himself writes about leftist cosmopolitan social democracy. However, Mouffe rejects his approach because of the theoretical, and not ideological assumptions ${ }^{53}$.

49 Ch. Mouffe, Polityczność..., pp. 83-85; 93-99.

50 F. Biały, Koncepcje demokracji agonistycznej, Poznań 2018, pp. 67 ff.

51 Ch. Mouffe, Agonistyka..., pp. 33-34.

52 After: A. Wielomski, Podmioty uprawnione do prowadzenia wojen $w$ teorii Carla Schmitta, [in:] M. Kubiak, R. Wróblewski (eds.), Oblicza wspótczesnych wojen, Warszawa-Siedlce 2018, p. 260.

53 Ch. Mouffe, Polityczność.., pp. 119-121. 
Basing on her reflections concerning liberal democracy in the state, Mouffe does not postulate a cosmopolitan world, universum, but rather pluriversum. As she states, the world without hegemony is not possible; on the other hand, she is afraid of one world hegemony since it would lead to the creation of a hyper-power. For this reason, the only option of a just world order is pluralization of hegemony between particular states and blocks ${ }^{54}$. It is not possible to build centralized cosmopolitan political institutions because, contrary to the state, on the global level there is nothing like a global community. Political unification of the world is not only impossible but in practice it would mean the existence of one centralized hegemony which - instead of being an antidote to global problems - would generate new radical forms of antagonisms. According to Mouffe, a multipolar world postulated by her and considering the political will not remove conflicts but will reduce destructive antagonisms $s^{55}$.

According to the author of Agonistics, we also have to accept the fact that the future multipolar world will not be wholly democratic. Certain blocks will be based on the values of the democratic order because they recognize democracy as a product of the Western world. On the other hand, Mouffe demands a pluralized understanding of democracy itself which will be adjusted to the local traditions ${ }^{56}$. The set of democratic values based on individualism can be completely different in those cultures which put emphasis on collectivism ${ }^{57}$. Mouffe thinks that although certain countries or blocks lack democracy or human rights, we can try to have - as called by Raimundo Panikkar - their functional correspondents. Instead of imposing democracy and human rights in the world through cosmopolitan institutions, it would be better to look for their equivalents in other blocks by understanding the functions that those ideas perform in the Western block. If human rights in the culture of the West guarantee human dignity, we should find out whether in other cultures there are different solutions in this respect ${ }^{58}$. Mouffe also postulates looking at democratic institutional solutions in different culture circles. For example, she claims that political institutions which were left after colonizers in African countries led to a social and political break-up.

54 Ch. Mouffe, Democracy in a Multipolar World..., p. 553.

55 Ch. Mouffe, Agonistyka..., pp. 41-42.

56 Ch. Mouffe, Democracy in a Multipolar World..., p. 556.

57 Ch. Mouffe, Which world order: cosmopolitan or multipolar..., p. 462.

58 Ibidem, pp. 456-458. 
In these countries governments based on national agreement can prove more effective than enforced radical pluralism ${ }^{59}$.

According to Mouffe, pluralization of democracy and hegemony will in practice ensure maximum diversity of the world and its differentiation on the social and cultural level. On the political level it will make it possible to avoid "a clash of civilizations" as Samuel Huntington understood it.

\section{Towards agonist cosmopolitism}

Although I agree with a lot of statements by Mouffe which are presented above, I do think the concept of cosmopolitism deserves to be preserved and connected with agonism. The reason is not to artificially link contradictory orders but because I believe that cosmopolitan practices follow from the assumptions made by Mouffe herself. An inspiration for these reflections is for me the concept of agonistic cosmopolitanism by Tamara Caraus ${ }^{60}$ and the concept of agonistic global constitutionalism by Christof Royer ${ }^{61}$. Both these propositions take into consideration two criteria indicated by Sjors Borrit Wijlhuizen when he attempted to justify that basing on Mouffe's assumption it is possible to defend the centralized global order. The first criterion refers to the necessity of establishing the rules of legitimized contestation of the dominating order. The other points to the significance of a democratic expression of sovereign nations ${ }^{62}$.

According to Tamara Caraus, multiplicity of the actors putting forward claims in the global space requires the development of cosmopolitan institutions which would be based on a conflicting consensus. On the one hand, it is connected with a negative ability to question the hegemonic order, while on the other, with a positive community of commonly shared rules. In the global context, the way to do it should be a kind of “cosmopolitan conversion". It means limiting one's own claims, respecting the opponent and sharing common ethical and political principles.

59 Ch. Mouffe, Democracy in a Multipolar World..., p. 561.

60 T. Caraus, Towards an Agonistic Cosmopolitanism: Exploring the Cosmopolitan Potential of Chantal Mouffe's Agonism, «Critical Horizons Critical Horizons» 2016, vol. 17, No. 1, pp. 94-109.

61 C. Royer, Evil as a crime against humanity..., pp. 187-229.

62 S. B. Wijlhuizen, Hegemony, Sovereignty and Global Order. An Argument on the Possibility of a Centralised Global Order on the Basis of Mouffe's Realist Agonism, Leiden University 2018, p. 2 . 
Here Caraus refers to the motif of moving from an enemy to an opponent, which takes place within the agonistically understood democratic system. The same can happen in case of the "cosmopolitan conversion". The author points to a two-stage process here. The first stage means separating oneself from local and national affiliations and the meanings and ideas shared so far. At this stage cosmopolitan claims are negative through a kind of disidentification. But this negation is emancipative because cosmopolitanism requires another kind of politics with a new confirmation of freedom, justice and equality as the principles which are binding to all subjects. In this way the second stage appears ${ }^{63}$.

As emphasized by Caraus, taking Mouffe's concept into consideration makes it possible to understand that in case of global democracy the agonistic attitude is based on the tension between cosmopolitism and particularism of national communities. Therefore, "cosmopolitan opponents" turn out to be former enemies who gave up their particular claims treated in antagonistic categories in the name of claims based on the rules binding to everybody ${ }^{64}$. Another advocate of this approach, Ch. Royer thinks that the basic assumption is contained in the whole agonistic concept of politics that freedom, equality and multiplicity must be protected from those practices that want to question these values and this requires the establishment of a constitutional order (also worldwide) based on the norms recognized by all sides. Thanks to this, agonistic politics will defend itself from those conflicts which might threaten the foundations of the political community ${ }^{65}$. T. Carusa goes in a similar direction. She emphasizes that Mouffe speaks for the conflicting consensus, a situation where the opponents do have fundamentally divergent visions but there is a minimal level of common symbolic space, thanks to which the opponents know that they can treat each other in the categories of contradiction. Such reasoning leads Caraus to the concept of a "non-conflicting cosmopolitan consensus". It assumes that the principles of freedom and equality are superior values of demo-liberal hegemony. Nevertheless, because these principles give a possibility to question hegemony which they enforce, all subjects can accept them. According to Caraus, even Mouffe's vision of a multipolar world must assume that apart from a negative community there exists a positive common community of the shared principles. This means that on the

63 T. Caraus, Towards an Agonistic Cosmopolitanism..., pp. 101-103.

64 Ibidem, p. 103.

65 Ch. Royer, Evil as a crime against humanity..., pp. 217-227. 
scale of the whole of the world a symbolic unity can be established which will guarantee agonism ${ }^{66}$.

In this place, two important dimensions of differences should be emphasized between agonists on the grounds of cosmopolitanism. The first axis of the controversy concerns the scope of hegemony. On one side, we will see Mouffe with her proposition of pluralism of hegemony; on the other, we can place Caraus and Royer, who think that cosmopolitan institutions condition agonism. The second axis of the conflict concerns the way of perceiving cosmopolitanism and it can be presented vertically and horizontally. In the first one we place Mark Wenman, Janet Conway and Jakeet Singh, who put emphasis on the bottom-up view. Wenman even speaks for so-called militant cosmopolitanism, which can be a product of those social movements which are a kind of network identities. Their fundamental principle, which distinguishes them from religious or ethnic movements, is extraordinary multiplicity. Those movements are magma-like and their activities are hard to predict since they constitute an eternal process. The importance of those activities is real in the sense that their carriers are real social actors, and the postulated ideas and values are connected with their everyday experiences. In this way new rules of co-existence can be practiced bottom-up on the local, state and global levels ${ }^{67}$. What is important, Mouffe also positively refers to the contestation of the excluded due to the top-down globalization, and she even perceives it as only an acceptable form of cosmopolitanism. Likewise, Conway and Singh emphasize the importance of the social movements of the excluded and the subordinated in the Third and Fourth Worlds, but those researchers are intentionally situated in opposition to the tradition represented by Mouffe, who - in their opinion - recognizes the framework of liberal democracy. According to Conway and Singh, the agonistic power of movements contesting globalization which has cosmopolitan importance is that they globally change the content of hegemonic meanings in the counter-hegemonic direction. In the face of the reviving imperial globality, which is hidden in the legitimizing language of democracy but which has deeply non-democratic goals and consequences, many social movements express their own traditions of "radical democracy". They are an alternative to the hegemony of liberal democracy but at the same time they create a new cosmopolitan community of bottom-

66 T. Caraus, Towards an Agonistic Cosmopolitanism..., pp. 104-105.

67 M. Wenman, Agonistic Democracy..., pp. 263-296. 
up experiences of critical character ${ }^{68}$. On the other hand, John Dryzek is rather situated on the horizontal level of controversies about democratic cosmopolitanism. Rather than placing emphasis on the bottom-up movement, he emphasized the informal character of the practices of global democracy, speaking for its discursive variant. He emphasizes that advocates of cosmopolitan democracy favour institutional reforms of the global order without noticing that in the global dimensions institutions are weak from assumption. Therefore, non-institutional communicative relations, which are to understand the significant discursive meanings, are even more important. Some of them are connected with the authorities (e.g. neoliberal capitalism), others broaden the area of inclusion and social articulation (e.g. alter-globalism) ${ }^{69}$.

The problem is that Conway and Singh as well as Dryzek treat global democracy in a reductionist manner, whereas Caraus and Royer propose a more complex approach. Their view emphasizes that it is only the establishment of common institutions and norms which enable contestation practices. Royer in particular considers both the bottom-up (social movements) and the top-down (common regulations) dimensions. In this way the top-down practices of agonistic institutions will always be under the pressure of political practices of the bottom-up and at the same time counter-hegemonic character, which will ensure agonism. On the other hand, Caraus is the opinion that transferring political institutions onto the global level provides new possibilities of articulating interests, which is impossible with the state paradigm. What is more, Caraus thinks that her concept, like Mouffe's, is in this respect based on negation because particular articulations of subjects are not simply an expression of their interests but they follow from the positions occupied within hegemony, which can be either confirmed or questioned but it can never be wholly closed. The logic of the agonistic struggle in the scheme of reasoning presented by Caraus proceeds then in a completely different way from that in cases described by Wenman, Conway and Singh. Referring to Mouffe, Caraus claims that contestation does not mean withdrawing from the existing institutions with the aim to support self-organization of civic society but on the contrary, contestation means involvement in the existing hegemonic institutions ${ }^{70}$ since no universality is established once and for all. The same path is followed

68 J. Conway, J. Singh, Radical Democracy in Global Perspective: notes from the pluriverse, «Third World Quarterly» 2011, vol. 32, No. 4, pp. 703-704.

69 J. Dryzek, Two Paths to Global Democracy, «Ethical Perspectives» 2008, No. 4, pp. 469-486.

70 T. Caraus, Towards an Agonistic Cosmopolitanism..., p. 106. 
by Royer, who bases on James Tully's agonistic constitutionalism and states that the constitutional order in the state, or in an international structure should open up channels of articulation within the frameworks of a political community ${ }^{71}$.

Whether speaking about installing institutions or exclusively about bottom-up practices, all agonists of key importance are conscious that it is not fully possible to overcome the idea of cosmopolitanism, also on the axiological level. According to Caraus, if the identity of a people is never fully constituted inside the liberal tradition, if it constitutes the platform of a permanent struggle for hegemony, then the identity of the Western block will also always remain in the course of being created. Therefore, it is hard to speak about enforcing the values of the Western world as they are after all never fully developed and closed, which makes the western circle only a discursive construction. According to Caraus, Mouffe is, however, afraid of a unipolar world and that is why she wishes to pluralize hegemony. But in this way she practically reduces hegemonic relations to a few blocks, while in the global system based on the rules of agonist cosmopolitanism a much deeper pluralization of identities and interests would take place ${ }^{72}$. This logic of reasoning is also adopted by Royer for whom the key condition for agonism to appear must be the establishment of a global constitutional order based on the commonly binding norms. For him, the fundamental question is why certain values are broken if they are so common. Royer's answer is cognitively radical. He believes that despite a common normative order it is not possible to fully establish agonistic relations; hence, antagonistic hostility is then an immanent component of political life. And this is why the establishment of universal norms also in the global sphere is not important. They are supposed to protect the human multiplicity and diversity from evil. The point is both top-down activities, including the use of forces by the international community with the aim to protect, for example, from genocide, and the bottom-up politics, which means an expression of counter-hegemonic movements ${ }^{73}$.

71 Ch. Royer, Evil as a crime against humanity..., pp. 206-209.

72 T. Caraus, Towards an Agonistic Cosmopolitanism..., p. 100.

73 Ch. Royer, Evil as a crime against humanity..., pp. 221-223. 


\section{Conclusions}

Basing on the reflections above, I think that Mouffe's antithetic treatment of cosmopolitan democracy and the agonistic order on the global level not fully coherent with her own assumptions. As a consequence, just like the classical cosmopolitan vision can lead to pluralism without antagonism, in the same way Mouffe's postulate of a multipolar order can lead to pluralist antagonism without agonism. In the first variant we have to do with annihilation of the political, while in the other - with its surplus, removing the possibility of establishing a field of agonistic global politics. The concept of agonistic cosmopolitanism developed by Tamara Caraus is an attempt to overcome these difficulties.

My conviction is that agonistic democracy is - like any other order - a historical practice and as such it does not appear until a certain stage in the development of democracy. And more exactly, it is a critical response to the hegemonic order of liberal democracy. It is aimed at ontological and epistemological deconstruction, and on this basis - also political diversification and the creation of articulation channels for different and opposing groups, and the institutional conditions of co-existence for them according to the principles not of hostility any longer but opposition according to the principles of agonistic consensus. We can state per analogiam that like classical Marxism assumed that proletarian revolution should be preceded by liberal revolution, in a similar way in relation of the post-Marxist approach Mouffe's radical agonistic politics is possible only within liberal democracy. And continuing this thread: the agonistic global order is possible only after the establishment of at least institutional fundamentals of global liberal democracy in the cosmopolitan spirit. From the agonistic point of view, it should not, however, be the end but the means to the end, which is radical pluralization of global democracy, but within its common institutions. The agonistic conflict is possible only within the frameworks of the cosmopolitan global order, which at the same time ensures the fundamental principles as well as the possibility of questioning them. The problem with the multipolar world is that we have to do with the reductionist pluralization of hegemony. Not until, however, particular poles appear within hegemony of higher order will it be possible to create a truly agonistic global order which will effectively cope with different global dangers. That is the reason why I believe agonists should not negate different improvements of international organizations or criticize such propositions as the world parliament. It would also be a mistake to ignore different variants of global governance - both in the 
classical version of relations between different institutional entities creating global public power and in reference to communicative discursive relations proposed by John Dryzek which in a democratic way create the binding meanings affecting real political decisions ${ }^{74}$.

It should also be added that there are moments when Mouffe herself seems not to avoid cosmopolitanism although in this case, too, she performs its deconstruction. Referring to the concept of de Sousa Santos concerning human rights, she supports his pluralization of cosmopolitanism filtering of this concept through various contexts and forms of cultural articulation. This is aimed to depart from the hegemonic tradition of the West and from the top-down form of globalization. Mouffe wants - like Sousa Santos - to connect human rights with the discourses of counter-hegemonic group excluded in the countries of the South. And it is in this context that she refers to the concept of cosmopolitan globalization, having in mind a kind of global community of the excluded because of top-down globalization. In this way, Mouffe indirectly acknowledges that there are some common frames on the global level ${ }^{75}$.

I do not claim in the present paper that agonistic cosmopolitanism will lead to full democratization of the world. I do believe, however, that the activities for radical pluralization within the frameworks of a network of institutions and cosmopolitan practices will ensure certain democratic values and procedures (e.g. transparency of the process, representation of differentiated social interests), which will bind to all entities involved in the construction and persistence of the new global order. In this way non-democratic states will function within the structure of common global interrelations, which can with time enforce the process of their democratization. If, however, this is to take place without any greater tensions, this process must be coherent with the cultural codes of each country.

\section{Bibliography}

Archibugi D., Cosmopolitan Democracy and its Critics: A Review, «European Journal of International Relations» 2004, vol. 10, No. 3.

Archibugi D., Principles of cosmopolitan democracy, [in:] D. Archibugi, D. Held, M. Köhler (eds.), Re-imagining political community: studies in cosmopolitan democracy, Stanford University Press 1998.

74 What is interesting, J. Dryzek himself, despite the differences in comparison to Mouffe emphasizes the importance of agonism. Foe more, see: J. S. Dryzek, Deliberative Democracy in Divided Societies: Alternatives to Agonism and Analgesia, «Political Theory» 2005, vol. 33, No. 2, pp. 218-242.

75 Ch. Mouffe, Which World Order..., pp. 459-460. 
Archibugi D., Held D., Cosmopolitan democracy: an agenda for a new world order, Polity Press 1995.

Bauman Z., Globalizacja: i co z tego dla ludzi wynika, Warszawa 2006.

Beck U., The Cosmopolitan Society and its Enemies, «Theory, Culture and Society» 2002, vol. 19 , Nos. $1 / 2$.

Beck U., Społeczeństwo ryzyka. W drodze do innej nowoczesności, Warszawa 2004.

Beck U., Wtadza i przeciwwładza w epoce globalnej. Nowa ekonomia polityki światowej, Warszawa 2005.

Biały F., Koncepcje demokracji agonistycznej, Poznań 2018.

Brauer M., Bummel A., A United Nations parliamentary assembly a policy review by Democracy Without Borders, Democracy Without Border, Berlin 2020.

Caraus T., Towards an Agonistic Cosmopolitanism: Exploring the Cosmopolitan Potential of Chantal Mouffe's Agonism, «Critical Horizons Critical Horizons» 2016, vol. 17, No. 1.

Conway J., Singh J., Radical Democracy in Global Perspective: notes from the pluriverse, «Third World Quarterly» 2011, vol. 32, No. 4.

De Búrca G., Developing Democracy Beyond the State, «Columbia Journal of Transnational Law» 2008, vol. 46, No. 2.

Dryzek J.S., Two Paths to Global Democracy, «Ethical Perspectives» 2008, No. 4.

Dryzek J.S., Deliberative Democracy in Divided Societies: Alternatives to Agonism and Analgesia, «Political Theory» 2005, vol. 33, No. 2.

Falk R.A., Strauss A., Toward global parliament, «Foreign Affairs» 2001, vol. 80, No. 1.

Friedman T.L., Świat jest plaski: krótka historia XXI wieku, Poznań 2009.

Friedman T.L., Lexus i drzewo oliwne: zrozumieć globalizacje, Poznań 2001.

Held D., Cosmopolitanism: globalisation tamed?, «Review of International Studies» 2003, vol. 29, No. 4.

Held D., Democracy and the global order: from the modern state to cosmopolitan governance, Stanford University Press 1995.

Hicks D., Thirty Years of Global Education: A reminder of key principles and precedents, «Educational Review» 2003, vol. 55, No. 3.

Kennedy P.T., U progu XXI wieku: (przymiarka do przyszłości), London 1994.

Laclau E., Mouffe C., Hegemonia i socjalistyczna strategia: przyczynek do projektu radykalnej polityki demokratycznej, Wrocław 2007.

Lim J.-H., What is Critical in Critical Global Studies?, «Global Studies in East Asia» 2017, vol. 10, No. 16, https://www.21global.ucsb.edu/global-e/march-2017/what-critical-critical-global-studies (12.01.2021).

Little A., Lloyd M., The politics of radical democracy, Edinburgh University Press 2009.

Macdonald K., Global democracy for a partially joined-up world toward a multi-level system of public power and democratic governance?, [in:] D. Archibugi, M. Koenig-Archibugi, R. Marchetti (eds.), Global democracy normative and empirical perspectives, Cambridge University Press 2012.

Macdonald T., Global stakeholder democracy power and representation beyond liberal states, Oxford University Press 2008.

Mannheim K., Ideologia i utopia, Lublin 1992.

Marchetti R., Global democracy: for and against: ethical theory, institutional design and social struggles, Routledge 2008.

Matijasevich D., Radical democracy and its limits, Palgrave Macmillan 2019.

Mouffe C., Democracy in a Multipolar World, «Millennium: Journal of International Studies» 2009, vol. 37, No. 3. 
Mouffe C., Which World Order: Cosmopolitan or Multipolar?, «Ethical Perspectives Ethical Perspectives» 2008, vol. 15, No. 4.

Mouffe C., Paradoks demokracji, Wrocław 2005.Mouffe C., The return of the political, Verso, London-New York 1993.

Mouffe C., Agonistyka: polityczne myślenie o świecie, Warszawa 2015.

Royer C., Evil as a crime against humanity: confronting mass atrocities in a plural world, Palgrave Macmillan 2021.

Ruggie J.G. (ed.), Multilateralism matters : the theory and praxis of an institutional form, Columbia University Press 1993.

Schmitt C., Pojęcie polityczności, [in:] C. Schmitt, Teologia polityczna i inne pisma, Kraków 2000.

Wenman M., Agonistic Democracy. Constituent Power in the Era of Globalisation, Cambridge University Press 2013.

Wielomski A., Podmioty uprawnione do prowadzenia wojen $w$ teorii Carla Schmitta, [in:] M. Kubiak, R. Wróblewski (eds.), Oblicza wspótczesnych wojen, Warszawa-Siedlce 2018.

Wijlhuizen S.B., Hegemony, Sovereignty and Global Order. An Argument on the Possibility of a Centralised Global Order on the Basis of Mouffe's Realist Agonism, Leiden University 2018. 